\title{
Impact of Corporate Social Responsibility on Job Attitudes: Job Satisfaction and Organizational Commitment of Banking Sector Employees of Pakistan
}

\section{Mavra Khan}

University of the Punjab, Lahore, Pakistan

Sadia Sarwar

State Bank of Pakistan

Hiba Khan

University of the Punjab, Lahore, Pakistan

\section{Abstract}

The study is conducted to highlight the employees' perspective of CSR in the banking sector of Pakistan and its impact on their job attitudes: job satisfaction and organizational commitment. Primary data were collected from 177 employees working in 22 different banks of Lahore (Pakistan). Stratified random sampling technique was used for sample selection. The population included all the banks in Lahore. Results show the existence of a direct relationship between a) CSR and Organizational Commitment b) CSR and Job Satisfaction.

Keywords

Corporate Social Responsibility, Job Satisfaction, Organizational Commitment, Dissonance Theory, SIT (Social Identity Theory), Organizational Justice Theory 


\section{Introduction}

According to (Ademosu, 2008) CSR (Corporate Social Responsibility) is contribution of an organization towards political, social, education and economic development of the society and the region where it works. Corporate Social Responsibility (CSR) is something which is not a law. Similarly Ogungbayi said that CSR is a way of thanking and paying back to the community, society and environment in which an organization works. Today the increasing awareness at global level, especially in the corporate sector, about the importance of social responsibility is helping to maintain the balance, environment and economy of the society without neglecting any of them leading to sustainable development (Maria João Santos, 2006). Sustainable development means to fulfill the needs of present in such a way that our successors will not have to compromise on their needs (Adrian Wilkinson, 2001). As the business sector is concerned about sustainable development so they made CSR an important part of their policy. Active involvement of companies in social activities now-a-days doesn't necessarily mean that people in the past were not concerned about their social responsibilities, the difference in the past and the present is that the companies did not include social activities as the integral part of their policies, however, they were well aware of its importance for the maintenance of a healthy society since centuries (Carroll, 1999; GAGO, 2005).

CSR got importance from 1950s in western world but the people of Asia are still lagging behind in understanding the true concept, depth, application, importance and worth of CSR. This article is an effort to unveil the value of CSR to the banks in Pakistan and to show how job satisfaction and organizational commitment are related to CSR.

The nature of the social activities performed by different organizations vary in strategy, procedures and priorities according to the nature of the organization (Neves \& Bento, 2005). The important thing is, every organization is playing its part for the betterment of the society (Philip Kotler, 2005; Windsor, 2001). Despite the importance of the employees for the working and performance of an organization, research on the impact of employee perception of company CSR on job attitudes and behaviors is insufficient (P. Rodrigo, \& Arenas, D, 2008). Employees are much concerned about the organization CSR, to participate in it, and to respond to company social responsibility, therefore they are the focus point for understanding how CSR impacts the organization's citizenship (Rupp, 2006).

Desired and preferred work outcome a Company can be the consequence of the positive job attitudes through CSR perception of employees. Supreme importance is given to improving the employee's job attitudes in management sciences (Brief, 2002). To understand how CSR relates to Job Satisfaction we should define job satisfaction. Job satisfaction is an employee's positive affective orientation towards a job (Smith, 1969). On one hand some researchers consider job satisfaction as a global concept which represents overall satisfaction. On the other hand job satisfaction can also be considered as a part-specific concept which represents satisfaction regarding different aspects of work like payroll, working condition, workload etc (Cook, 1981), absenteeism, turnover, decision to retire lateness and other withdrawal behaviors (Hulin, 1985; Jaramillo, 2006), organizational commitment (Gomes, 2009; J. Meyer, Stanley, D., Herscovitch, L. \& Topolnytsky, L. , 2002), organizational justice (Colquitt, 2001), perceived organizational support (Eisenberg, 2002), life satisfaction (Judge, 1993) and burnout (Bacharach, 1991). 
The most recent perspective of job satisfaction is that it is an "attitude" or the positive or negative opinion about one's job or it's working conditions (Weiss, 2002). (Weiss, 2002). Job satisfaction shows the satisfaction, appreciation, aspiration and the contentment an employee feels from one's job and other things related to the job. It is not considered as an affect but as an evaluation and judgment of the job. So here job satisfaction is considered as a job attitude.

Organizational commitment means a decision of the employee to stay within his organization. Reasons for remaining with that organization can be: satisfaction with his job, emotional attachment with that organization, benefits, salary package etc. According to Allen (1990) "It is a psychological condition that indicates an employee's relationship with his corporation and affirms decision to continue that relationship".

In Pakistan CSR is at its initial stages. Only few companies are following the policies prescribed by "The Constitution of Pakistan" about CSR. The multinational companies working in Pakistan are following their own CSR policies. The corporate culture of Pakistan is facing such adverse social and economic conditions that it requires the implementation of a proper CSR policy to up root the factors causing these conditions. Certain important principals are introduced by the Constitution of Pakistan in these policies regarding CSR. Without giving CSR a vital place in our corporate culture, some economic and social problems, like poverty, cannot be eradicated. The variables CSR, job satisfaction and organizational commitment are discussed in this article on the base of three theories i.e. SIT (social identity theory), organizational justice theory and dissonance theory.

\section{Literature Review}

Literature indicates that SIT give detail that there is relationship between CSR involvement of an organization and work attitudes and behaviors of its employees. Social identity theory depicts that employee feel proud to be associated with a firm working for the society and have good external reputation (Ashforth B. E. and Mael, 1989; J. E. Dutton, Dukerich, J. M., and Harquail, C. V 1994; Gavin, 1975; I. Maignan, \& Ferrell, O. C, 2001). Distinctive knowledge, expertise and mechanisms on the base of that knowledge enables an organization to perform perfectly its additional duties and activities (Sharma, 1998; Teece, 1997). Social identity theory explains that if employees have a feeling of proud on being attached with a corporation which is socially responsible, it positively affects their attitudes towards the organization positively(Ashforth B. E. and Mael, 1989; S. Brammer, A. Millington and B. Rayton, 2005; J. E. Dutton, J. M. Dukerich and J. M. Harquail, 1994; I. Maignan, 2001; Peterson, 2004b).

Employees are very important internal stakeholders of an organizational so they do care whether the organization is performing all of its social responsibilities or not (P. Rodrigo, \& Arenas, D., 2008) and it also effects their performance and job attitudes greatly. Organizational justice theory is designed to explain it. It is the theory which determines the way in which employees perceive if their organization treats them fairly or not (Moorman, 1991). So it can be said that the employees' perception of their organizational justice can be framed by CSR (Rupp, 2006). 
Employees' belief that their organization is fair with the society may develop the idea that the organization will also be fair with them. This thought may lead to job satisfaction.

Organizational justice theory also provides the employees with the feeling that their psychological needs about fairness would be fulfilled by the organization. Employees' this belief will develop in them positive feelings for their organization. The feeling of being treated fairly will help employees to trust their organization which will result in positive job attitudes (Leigh, 1988). It means if employees' perceived CSR activities are performed by the organization then a positive change may be observed in the job attitudes of the employees and the employees may show organizational commitment. According to the dissonance theory, when employee consider employer more ethical and socially responsible, the conflicts between employees and organization decreases and job satisfaction increases (Viswesvaran, 1998).

On the basis of these theories the relationship between CSR, job satisfaction and organizational commitment will be discussed. The reasons for the increased involvement of organizations in CSR activities are the pressure groups e.g. employees, investors, customers etc. (S. Brammer, \& Millington, 2003) and new growing market for the ethical values such as increasing investment in social activates motivates the company to generate the CSR policy (Vogel, 2005). Some individuals and groups as stakeholders show their concern towards the corporate policies and activities because they can affect or can be affected by them (Freeman, 1984). Major part of the literature shows that any company's participation in the CSR has greater impact on both job attitudes and behaviors of the internal and external stakeholders.

Employee's perception of CSR is the focal point in CSR adoption of a company. As a stakeholder of a company employees are the central group which must be considered during practicing CSR activities (d'Humières, 2001). According to Aimee Dars Ellis, employee perception of CSR is based on three stages:

- Awareness of CSR.

- Employee perception of CSR policy "fit".

- Employee perception of CSR policy motivation

Awareness of CSR can lead to the positive perception of employees (S. Sen, Bhattacharya, C. B., \& Korschun, D, 2006) but CSR policy "fit" is necessary for positive perception. Congruency between firms CSR and its strategies results in effective employee perception of CSR (Ellis). "Fit" constructs the idea that CSR activities of an organization must support main business line of the organization. It is described as the activities of the organization must be according to its skills (Porter, 2006; S. Sen, \& Bhattacharya, C. B, 2001). Theoretical proposals and empirical studies depicts that compliance of CSR activities with the main business and corporate environment, consideration of social welfare are the factors behind the effective application of CSR strategies (Porter, 2006). Cause of the Positive perception of CSR activities is the satisfaction of the employees with the above mentioned factors (e.g. CSR capability and perceived cultural fit) that effect their job attitudes and organizational commitment (Eun Mi Lee 2012).

A. B. (1979) Carroll, (1979) study defines the four dimensions of CSR economical, legal, ethical, and discretionary (philanthropic) and CSR in societal perspective is more positively perceived. CSR have a broad range of actions in these four dimensions, it 
includes activities that are further than the interests of firms and away from the only requirement of law (McWilliams, 2001). A firm's knowledge about society and its skills to serve society, ability of planning, effective techniques to implement the planning and analysis of activities is regarded as the "CSR Capability". Under the light of this definition of CSR capability, researchers proved that employees of a firm having capability of effective planning, organizing and implementing the CSR program are more positively understanding the CSR activities of their firm (Eun Mi Lee 2012).

Perception of the employees about the fair and honest activities of the organization generate positive changes in their attitudes and behaviors (Cropanzano, 2001). Employee's perception of CSR activities of the company effects their job attitudes (job satisfaction and organizational commitment) and behaviors. Positive impacts of CSR on the internal environment (workplace behavior) and on the attitudes (organizational pride, satisfaction, and commitment, in role performance) of the internal stakeholders of the company have been depicted in the previous studies(S. J. Brammer, Millington, A. I., \& Pavelin, S, 2006; Dutton, 1991; Ellemers, 2011; Jones, 2010; Lin, 2010; Peterson, 2004a; Riordan, 1997; Valentine, 2008). CSR is the voluntary behavior of the company towards the society and community. The positive response from the external environment e.g. family and friends cause the job satisfaction and organizational commitment of the employees because they feel privilege for such social welfare activities of their organization (Riordan, 1997). General concept is that more people want to be more committed to the organization that is socially responsible.

In existing literature, job satisfaction is defined as "it is a state of attitude which shows either an individual likes or dislikes his work (Saari LM, 2004). This attitude further increase employee personal perception and enhance the good relationship between organization and the individual (Lok P, 2001). Study of Antoncic J.A. (2011) indicates the four factors which comprise the job satisfaction; a) general satisfaction with work, b) employee relationship, c) remuneration and benefits provided by the company and d) employee loyalty. There is positive relationship between positively perceived CSR and job satisfaction (Sean Valentine, 2008).

Job satisfaction can also be defined as the positive emotional state which an individual attains when he/she is satisfied with his/her work (Locke, 1976). This satisfaction is the result of a large no of experiences of different nature and these experiences include different characteristics of job satisfaction and the work environment. So the variable that depends on different aspects of the relationship between individual and work is called " job satisfaction" (Zheng, 2010). The activities of an organization directly affect its employees' job attitudes and job behaviors and forms the basis of employees' perception about their organization (Zheng, 2010).

According to the four categories of CSR (A. B. Carroll, 1979), the legal, economic, ethical and discretionary activities performed by the organization forms the basis of the perception of its employees which is related to their CSR perception (I. Maignan, \& Ferrell, O, 2001). Many important organizational variables are considered and evaluated to measure the job satisfaction (Spector, 1997). One of them is CSR. CSR as compared to the ethics program create greater job satisfaction because CSR depicts social response that ultimately satisfies the social needs of the employee as well and cause their job satisfaction (Sean Valentine, 2008).The relationship between CSR and organizational commitment is studied by different researchers. Employee perception of CSR practices of 
a company has a direct effect on organizational commitment (Imran Ali, 2010). (Imran Ali, 2010). In 2007 the research of (S. Brammer, Millington, A., \& Rayton, B, 2007) identified that there is a positive relationship between organizational commitment and CSR practices as perceived by employees.

Organizational commitment is an important dimension of the work attitudes of the employees. It can be described as the psychological identification that has been felt by an individual towards his or her organizing (Mowday, 1982). Organizational commitment means a relationship between organization and employee and he decided to keep up this relation (J. P. a. N. J. A. Meyer, 1997). An Individual joins an organization with some needs and hopes towards organization, seeks opportunities to implement his skills and abilities. He expects to work in good working environment, feels safety, find recognition of his work and other factors which satisfies his needs. If an organization fulfills such needs of the individual, it enhances his organizational commitment level (Vakola, 2005). Brammer et al. (2007) conducted a study in which a sample of 4712 employees from financial services companies was taken in order to find out the relationship between CSR and job satisfaction. Both internal and external CSR were measured. For the measurement of internal CSR 6 items were used to measure procedural justice and 3 items were used to measure provision of training opportunities. To measure external CSR 1 item was used to measure community involvement. Job satisfaction was measured by using 28 items taken from Spector's (1997) "Job Satisfaction survey". The results showed a positive relationship between internal CSR (justice perceptions and training provision), external CSR (community involvement) and job satisfaction. (Imran Ali, 2010). In 2007 the research of (S. Brammer, Millington, A., \& Rayton, B, 2007) identified that there is a positive relationship between organizational commitment and CSR practices as perceived by employees.

The purpose of this study is to analyze the nature of relationship between employees' perception of CSR and job satisfaction and CSR and organizational commitment. Past studies have proved that there is positive relation between CSR and organizational commitment. On the base of the social identity theory, Turker (Turker, 2009) has proved the positive link between organizational commitment and CSR. According to Peterson (2004b) there is direct relationship between CSR and organizational commitment especially in an organization which is satisfying the needs of its employees and its employees are satisfied with their jobs. CSR activities of a corporation causes employee satisfaction with their job and this satisfaction effects their commitment with organization positively (Kim HR, 2010). If employee believes he is working in a socially responsible organization, it cause greater job satisfaction and he wants long relationship with such organization (Dunford, 2011). A company which is meeting the expectations of its employees regarding CSR and general business ethics values, can expect better job attitudes and behaviors, greater productivity and lower turnover (Trevino, 2004; Tuzzolino, 1981).

SIT theory explains that individuals want to define themselves in social context and for which they want to be identified and identify others in different categories (Ashforth B. E. and Mael, 1989; J. E. Dutton, J. M. Dukerich and J. M. Harquail, 1994; Tajfel, 1985). It is considered that job satisfaction plays both mediating and moderating role between employee perception of CSR and organizational commitment (Qinghua Zhu, 2012). It can be seen that the focus of researchers has been the European countries always. Unlike 
other researches being conducted in Europe, this research is conducted in an Asian country Pakistan. This research is an effort to cover the research gap in literature regarding CSR, job satisfaction and organizational commitment in perspective of Pakistan. This article will provide the banking industry of Pakistan an insight into the matters related to the variables discussed in this article.

\section{CSR in Pakistan}

The fact that Pakistan is included in the list of those 20 countries which are facing some difficulties of serious nature again increases the importance of CSR implementation many folds. As corporate sector is a very important part of civil society so it should make a noticeable contribution in the implementation of CSR practices and procedures but the reality is that only few companies are discharging their CSR activities. Out of these few companies most of them are multinational companies. A small number of local companies are found interested in CSR. The multinational companies are following their own CSR policy but the local companies are following the CSR policy prescribed by the Constitution of Pakistan.

The failure of proper performance of the CSR activities became visible after the downfall of Sialkot sports industry and the local carpet industry. International researchers pin pointed some reasons of this failure which are labor exploitation, inadequate employee benefits, child labor and unsuitable working environment. The industrialists took some quick measures to prevent this situation from becoming even worse but these were not enough. The Government of Pakistan should help corporate sector by every mean to save the economic and social structure of the country. A complete cooperation is required by the Government at all the levels i.e. tax relief, co-funding and increased incentives.

In Pakistan the corporate philanthropy is confused with CSR. The Government of Pakistan should start an awareness campaign to clarify the difference between these and the target of this campaign should be businessmen, entrepreneurs and customers. Frequent and open discussions should be held to promote the importance and need of CSR in corporate sector.

Hypothesis

H1: Employee's perception of CSR is directly related to job satisfaction and organizational commitment.

\section{Methodology}

Population of this study consists of branches of private and government banks in Lahore. "Stratified Random Sampling" technique was used in this study. By using "stratified random sampling technique" the banks were divided into "Public" and "Private" banks. After making strata "lottery method" was used to select 22 banks randomly from all the public and private banks. In the end, "Convenience Sampling Technique" was used to select the sample which was used for data analysis. The sample includes 177 employees from different branches of 22 banks.

In this study "Close-ended Questionnaire" was used as the tool for data collection. The questionnaire consisted of 48 measuring items. It was divided into three parts. It had 34 items in first part, 9 items in second part and 6 items in third part to measure employees' 
perception of corporate social responsibility (CSR), organizational commitment and job satisfaction respectively. Likert-type scale ranging from 1 (strongly agree) to 5 (strongly disagree) was used for the first and the second parts of the questionnaire. For the third part of the questionnaire likert-type scale ranging from 1 (very unsatisfied) to 5 (very satisfied) was used.

In this study "Close-ended Questionnaire" was used as the tool for data collection. The questionnaire consisted of 48 measuring items. It was divided into three parts. It had 34 items in first part, 9 items in second part and 6 items in third part to measure employees' perception of corporate social responsibility (CSR), organizational commitment and job satisfaction respectively. Likert-type scale ranging from 1 (strongly agree) to 5 (strongly disagree) was used for the first and the second parts of the questionnaire. For the third part of the questionnaire likert-type scale ranging from 1 (very unsatisfied) to 5 (very satisfied) was used.

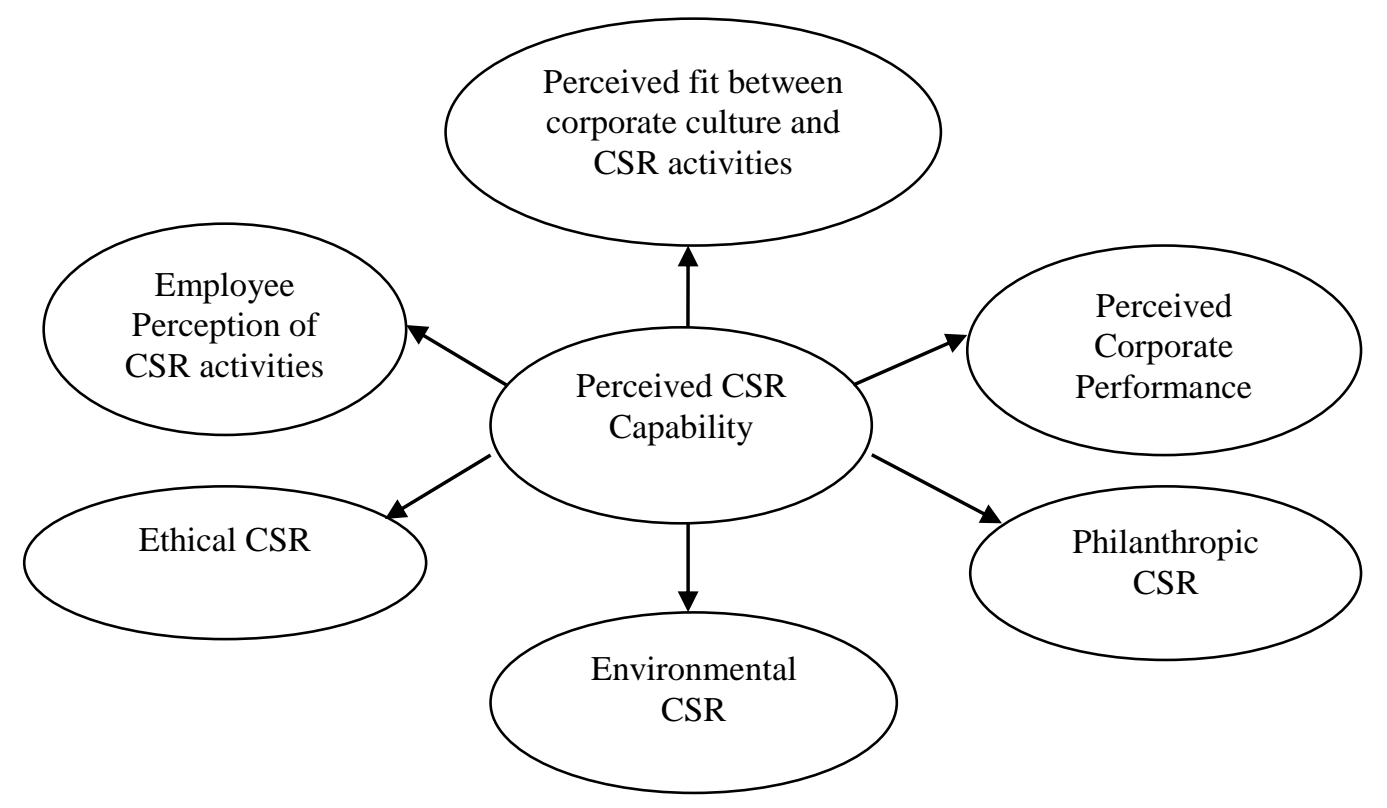

Figure 1- Employee Perception of CSR Activities Dimensions

All of the measures used in this study were taken from existing literature and adapted in the context of the current study. The items used in the questionnaire for the measurement of the employees' perception of CSR were taken from the article "Employee perception of CSR activities: Its antecedents and consequences". This article was written by Eun Mi Lee, Seong-Yeon Park , Hyun Jung Lee (2011). It was mentioned in this article that to make their CSR scale, the researchers used the work of some other researchers. These were Cable \& DeRue, 2002, Vorhies \& Morgan, 2003, Lichtenstein et al., 2004. Maignan \& Ferrell, 2001, Montgomery \& Stone, 2009. The CSR perception in different dimensions discussed in the above mentioned article and used in questionnaire of this article is shown in the figure 1 given above.

In this research the scale used for job satisfaction measurement was taken from the work of Ana Patrícia Pereira Duarte Baltazar (2011) who further in her study used the scale of the researchers (Balzer \& Gillespie, 2006; Lima et al., 1994; Saari \& Judge, 2004). Lima and her colleagues used a scale of five items which were measured on 1-5 likert scale 
starting from strongly unsatisfied (1) to strongly satisfied(5). These items measure employees' satisfaction regarding their company, co-workers, payroll, supervisor and their work. Ana Patrícia Pereira Duarte Baltazar (2011) added one more item to the scale to measure overall level of job satisfaction and the resulted 6 item scale is used in this study.

For the measurement of Organizational commitment, the scale was adopted from the work of Ana Patrícia Pereira Duarte Baltazar (2011). It is a nine item likert scale ranging from (1) strongly agree to (5) strongly disagree. This scale was developed by Meyer and colleagues (1993) and Ana Patrícia Pereira Duarte Baltazar (2011) used it in her study. The first three items of the scale measure effective commitment, next three items assess normative commitment and the last three measure continuance commitment. After using all above mentioned scales, a questionnaire having 48 items was developed.

\section{Theoretical Framework}

On the base of literature a theoretical framework was developed which is as follow:

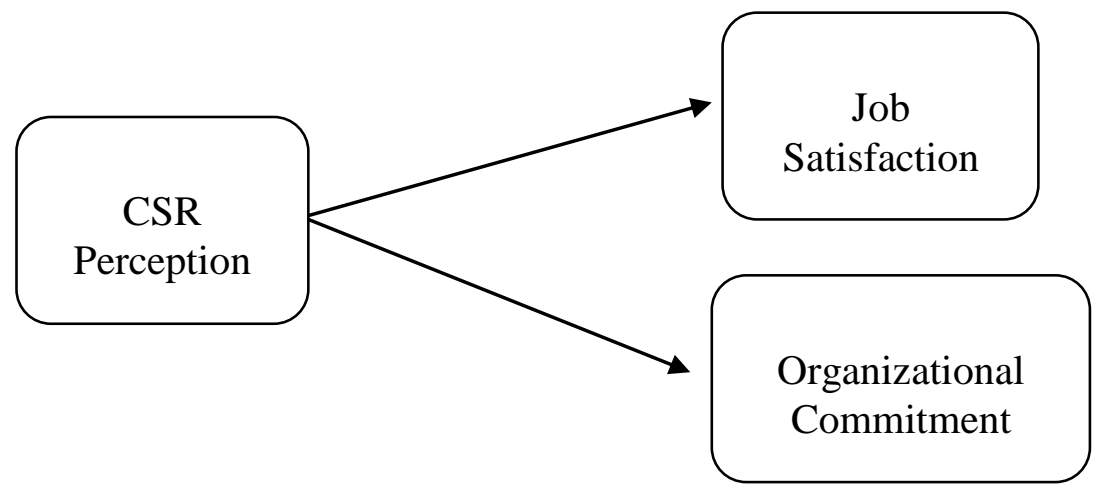

Figure 2- Theoretical Framework

CSR stands for Corporate Social Responsibility and is acting as independent variable, job satisfaction and organizational commitment are acting as dependent variable

\section{Hypothesis Testing}

For testing hypothesis SPSS, a data analysis software, was used. Descriptive, correlation and regression tests were applied to check the hypothesis.

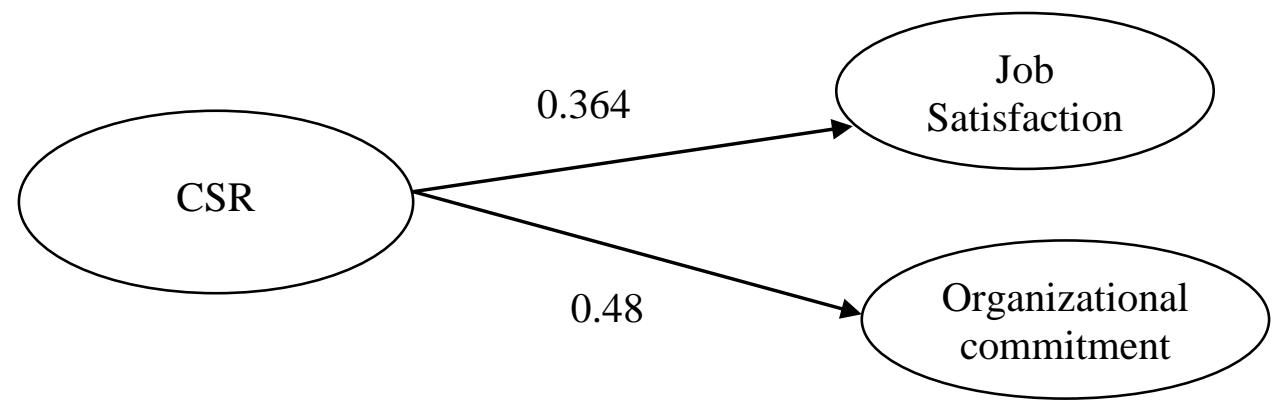

Figure- 3 Showing the Correlation Values between the Three Variables 
In order to check $\mathrm{H}_{\mathrm{A} 1}$ Correlation test was applied. Results in table 2 show that job satisfaction is positively related to organizational commitment and their correlation coefficient is 0.319 which is significant at $1 \%$. Correlation coefficient between CSR and organizational commitment is 0.481 which is significant at $1 \%$. Correlation coefficient between job satisfaction and CSR is .364 which is significant at $1 \%$. Hence $\mathrm{H}_{\mathrm{A} 1}$ is proved. In order to check the impact of change in CSR on job satisfaction and organizational commitment regression test was applied. The Table 1 shows that one unit change in CSR will bring $48.1 \%$ change in OC and this is significant at $1 \%$. The results in Table 1 show that 1 unit change in CSR will bring $36.4 \%$ change in job satisfaction this is significant at $1 \%$.

\section{Discussion}

Useful pieces of information, about the role of the variables, were found by data analysis which helped in determining the nature of the relationship existing between the concerned variables. The finding of this research can be compared with the finding of other researchers. Basically this study will help to get better insight about the employee perception of CSR and its link with job satisfaction and organizational commitment. It is clear from Table 1 that out of the three variables, job satisfaction and organizational commitment have highest maximum values and lowest minimum value is of JS. The highest mean value is of CSR which means most of the employees agree that their company perform CSR activities.

Table 1- Correlation between Organizational Commitment, Job Satisfaction and CSR

\begin{tabular}{cccccc}
\hline Model & $\begin{array}{c}\text { Unstandardized } \\
\text { Coefficients }\end{array}$ & $\begin{array}{c}\text { Unstandardized } \\
\text { Coefficients }\end{array}$ & $\begin{array}{c}\text { Standardized } \\
\text { Coefficients }\end{array}$ & $\mathrm{t}$ & Sig. \\
\hline (Constant) & $\mathrm{B}$ & Std. Error & Beta & & \\
CSR & 1.090 & 0.294 & & 3.712 & .000 \\
$\begin{array}{c}\text { Dependent variable: } \\
\text { OC }\end{array}$ & 0.595 & 0.08 & 0.481 & 7.250 & .000 \\
\hline $\begin{array}{c}\text { (Constant) } \\
\text { CSR }\end{array}$ & 1.541 & 0.373 & & 4.127 & .000 \\
$\begin{array}{c}\text { Dependent variable: } \\
\text { JS }\end{array}$ & 0.540 & 0.104 & 0.364 & 5.165 & .000 \\
\hline
\end{tabular}

In table no. 1 correlation coefficient was used to analyze the hypothesis. Hypothesis 1 investigated that whether CSR is related to job satisfaction and organizational commitment or not. The results in this table demonstrate Pearson correlation coefficients values for job satisfaction, organizational commitment and CSR and it also shows that the values are significant. It is clear from the table that there exists a positive relationship between job satisfaction and organizational commitment and their correlation coefficient is 0.319 and the value of significance for the correlation coefficient is 0.000 which means it is significant at $1 \%$.

Similarly it can be seen that the correlation coefficient between CSR and organizational commitment is 0.481 which means there also exists positive relationship between CSR and organizational commitment. The value 0.000 shows that the coefficient is significant 
at $1 \%$. It is also clear from the table that the correlation coefficient value for CSR and job satisfaction is 0.364. This value shows the existence of a positive relationship between CSR and job satisfaction. The value 0.000 depicts that this correlation coefficient is significant at $1 \%$. Hence the alternative hypothesis 1 is proved which states that CSR is related to job attitudes i.e. job satisfaction and organizational commitment.

To check the extent to which CSR affects Job Attitudes i.e. job satisfaction and organizational commitment regression analysis was conducted. First regression test was conducted to check the impact of CSR on Organizational Commitment. So, In Table 2 regression analysis of CSR and OC is conducted in which CSR is taken as independent variable and OC as dependent variable. Beta value is 0.481 which depicts 1 unit change in CSR brings $48.1 \%$ change in OC. This significant value shows there is a positive relationship between CSR and organizational commitment.

Table 2- Regression Analysis

\begin{tabular}{clccc}
\hline & & $\begin{array}{c}\text { Organizational } \\
\text { commitment }\end{array}$ & Job Satisfaction & CSR \\
\hline \multirow{2}{*}{ OC } & $\begin{array}{l}\text { Pearson Correlation } \\
\text { Sig.(2.tailed) }\end{array}$ & 1 & & \\
& $\mathrm{~N}$ & 177 & & \\
\hline \multirow{3}{*}{ JS } & Pearson Correlation & $.319^{* * *}$ & 1 &. \\
& Sig.(2-tailed) & .000 & 177 & \\
& $\mathrm{~N}$ & 177 & $.364 * * *$ & 1 \\
CSR & Pearson Correlation & $.481^{* * *}$ & .000 & 0.000 \\
& Sig.(2-tailed) & .000 & 177 & 177 \\
\hline
\end{tabular}

Second regression test check the link between CSR and job satisfaction. Table 3 shows CSR is entered as independent variable and Job satisfaction as dependent variable. Beta value is 0.364 which shows there comes $36.4 \%$ change in job satisfaction with 1 unit change in CSR, and this change is significant at $1 \%$. So it can be said that CSR has positive impact on job satisfaction.

\section{Conclusion}

From this study it is concluded that the perception of employees of banking sector of Lahore (Pakistan) is positive as they support and are satisfied with the CSR performance by their organization. This satisfaction with the CSR activities causes job satisfaction and organizational commitment which is clear from the data analysis. It means the employees are concerned about their society. The reputation of their bank is important for employees because it induces more confidence, reliability, satisfaction and commitment in them towards their bank. The theoretical framework of this research work is supported by its empirical result. This study provides helpful information for future researches. The literature review supported the hypothesis that there exist a positive relationship between CSR and organizational commitment. The data analysis provided the proof that for the employees of banking sector in Lahore, a city of Punjab, Pakistan, there exist a positive relationship between the variables. 
It is evident from the study that employees' perception of CSR has noticeable effects on employees' work outcomes. Employees are the primary stakeholders of an organization and their perception of CSR influences their work outcomes in an organization. So, CSR activities benefit both organization and their employees. This study suggests corporations to have active CSR programs which include not only shareholders but also all stakeholders.

\section{References}

Ademosu, E. A. (2008). Corporate Social Responsibility: The experience of the Nigeria Banking System.

Adrian Wilkinson, M. H. a. P. G. (2001). The sustainability debate. International Journal of Operations \& Production Management, 21(12), 1492-1502.

Allen, N., \& Meyer, J. (1990). The measurement and antecedents of affective, continuance and normative commitment to the organization. Journal of Occupational Psychology, 63, 1-3.

Antoncic JA, A. B. (2011). Employee satisfaction, intrapreneurship and firm growth: a model. Industrial Management \& Data Systems, 111(3-4), 589-607.

Ashforth B. E. and Mael, F. (1989). Social identity theory and organization. Academy of management review, 14, 20-39.

Bacharach, S., Bamberger, P., \& Conley, S. . (1991). Work-home conflict among nurses and engineers: Mediating the impact of role stress on burnout and satisfaction at work. Journal of Organizational Behavior, 12, 39-53.

Brammer, S., \& Millington. (2003). The effect of stakeholder preferences, organizational structure and industry type on corporate community involvement. Journal of Business Ethics, 45(3), 213-226.

Brammer, S., A. Millington and B. Rayton. (2005). The Contribution of Corporate Social Responsibility to Organisational Commitment, Working Paper. UK: University of Bath. 
Brammer, S., Millington, A., \& Rayton, B. (2007). The contribution of corporate social responsibility to organisational commitment. International Journal of Human Resource Management, 18(10), 1701-1719.

Brammer, S. J., Millington, A. I., \& Pavelin, S. (2006). Is philanthropy strategic? An analysis of the management of charitable giving in large UK companies. Business Ethics: A European Review, 15, 234-245.

Brief, A., \& Weiss, H (Ed.). (2002). Organizational behavior: Affect in the workplace. (Vol. 53). Palo Alto: Annual Reviews.

Carroll, A. B. (1979). A three-dimensional conceptual model of corporate performance. . Academy of Management Review, 4(4), 497-505.

Carroll, A. B. (1979). A three-dimensional conceptual model of corporate performance. Academy of Management Review, 4(4), 497-505.

Carroll, A. B. (1999). Corporate Social Responsibility: Evolution of a Definitional Construct. Businees and Society, 38(3), 268-295.

Colquitt, J., Conlon, D., Wesson, M., Porter, C., \& Ng, K. . (2001). Justice at the millennium: A meta-analytic review of 25 years of organizational justice research. . Journal of Applied Psychology, 86, 425-445.

Cook, J. D., Hepworth, S. J., Wall, T. D.,\&Warr, P. B. (1981). The experience of work. New York: Academic Press.

Cropanzano, R., Byrne, Z. S., Bobocel, D. R., \& Rupp, D. E. (2001). Moral virtues, fairness heuristics, social entities, and other denizens of organizational justice. Journal of Vocational Behavior, 58, 164-209.

d'Humières, P. C., A. (2001). Les pionniers de l'entreprise responsable (d ed.). Paris: Organization. 
Dunford, S. D. H. B. B. (2011). Corporate Social Responsibility and the Benefits of Employee Trust: A Cross-Disciplinary Perspective. Journal Business Ethics, 102, $29-45$.

Dutton, J. E., \& Dukerich, J. M. (1991). Keeping an eye on the mirror: The role of image and identity in organizational adaptation. Academy of Management Journal,, 34, $517-554$.

Dutton, J. E., Dukerich, J. M., and Harquail, C. V (1994). Organization images and member identification. Administrative Science Quarterly, 39, 230-263.

Dutton, J. E., J. M. Dukerich and J. M. Harquail. (1994). Organizational Images and Member Identification. dministrative Science Quarterly, 39(2), 239-263.

Eisenberg, R., Stinglhalmer, F., Vandenberghe, C., Sucharski, I., \& Rhoades, L. (2002). (2002). Perceived supervisor support: Contributions to perceived organizational support and employee retention. Journal of Applied Psychology, 87, 565-573.

Ellemers, N., Kingma, L., van de Burgt, J., \& Barreto, M. (2011). Corporate social responsibility as a source of organizational morality, employee commitment and satisfaction. Journal of Organizational Moral Psychology, 1, 97-124.

Ellis, A. D. The impact of corporate social responsibility on employee Attitudes and behaviors. , School of Business. New York.

Eun Mi Lee , S.-Y. P., Hyun Jung Lee. (2012). Employee perception of CSR activities: Its antecedents and consequences. journal of Business Reasearch, 66 1716-1724.

Freeman, R. E. (1984). Strategic management: A stakeholder approach. Boston: Pitman.

GAGO, C. C. C., Eduardo Gomes; CAMPOS, Jose Torres; VICENTE, Luiz Moura; SANTOS, Mario Cardoso. (2005). Responsabilidade social das empresas portuguesas: 25 casos de referência. Lisboa: [ S.I. ] : Companhia das Cores, Design e Comunicacao Empresarial, Setembro 2005 
Gavin, J. J., \& Maynard, W. S. (1975). Perceptions of corporate social responsibility

Personnel Psychology, 28(3), 377-387.

Gomes, D. (2009). Organizational change and job satisfaction: The mediating role of organizational commitment. Exedra, 1, 177-195.

Hulin, C. L., Roznowski, M., \& Hachiya, D. (1985). Alternative opportunities and withdrawal decisions: Empirical and theoretical discrepancies and integration. Psychological Bulletin, 97, 233-250.

Imran Ali, K. U. R., Syed Irshad Ali, Jamil Yousaf and Maria Zia. (2010). Corporate social responsibility influences, employee commitment and organizational performance. African Journal of Business Management, 4(12), 2796-2801,.

Jaramillo, F., Mulki, J., \& Solomon, P. . (2006). The role of ethical climate on salesperson's role stress, job attitudes, turnover intention, and job performance. Journal of Personal Selling \& Sales Management, 26(3), 271-282.

Jones, D. A. (2010). Does serving the community also serve the company? Using organizational identification and social exchange theories to understand employee responses to a volunteerism program. Journal of Occupational and Organizational Psychology, 83, 857-878.

Judge, T., \& Watanabe, S. (1993). . (1993). Another look at the job satisfaction-life satisfaction relationship. Journal of Applied Psychology, 78, 939-948.

Kim HR, L. M., Lee HT, Kim NM. (2010). Corporate social responsibility and employeecompany identification. Journal of Business Ethics, 95(4), 557-569.

Leigh, J. H., Murphy, P. E. \& Enis, B. M. . (1988). A New Approach to Measuring Socially Responsible Consumption Tendencies. Journal of Macromarketing, 8(1), 520 . 
Lin, C., Lyau, N., Tsai, Y., Chen, W., \& Chiu, C. (2010). Modeling corporate citizenship and its relationship with organizational citizenship behaviors. Journal of Business Ethics, 95, 357-372.

Locke, E. (Ed.). (1976). The nature and consequences of job satisfaction. Chicago: Rand McNally.

Lok P, C. J. (2001). Antecedents of organizational commitment and the mediating role of job satisfaction. Journal of Managerial Psychology, 16(8), 594-613.

Maignan, I. (2001). Consumers' perceptions of corporate social responsibilities: A crosscultural comparison. . Journal of Business Ethics, 30, 57-72.

Maignan, I., \& Ferrell, O. (2001). Corporate citizenship as a marketing instrument. European Journal of Marketing, 35, 457-484.

Maignan, I., \& Ferrell, O. C. (2001). Antecedents and benefits of corporate citizenship: An investigation of French business. Journal of Business Research, 51, 37-51.

Maria João Santos, A. M. S., Elisabete Nobre Pereira and José Luís de Almeida. (2006). Responsabilidade social nas PME: Casos em Portugal. Lisboa: RH Editora.

McWilliams, A., \& Siegel, D. (2001). Corporate social responsibility: A theory of the firm perspective. The Academy of Marketing Review, 26(1), 117-127.

Meyer, J., Stanley, D., Herscovitch, L. \& Topolnytsky, L. . (2002).

Affective,continuance, and normative commitment to the organization: A Metaanalysis of antecedents, correlates, and consequences. Journal of Vocational Behavior, 61, 20-52.

Meyer, J. P. a. N. J. A. (1997). Commitment in the Workplace: Theory, Research, and Application. Sage, Thousands Oaks, CA. 
Moorman, R. H. (1991). Relationship between organizational justice and organizational citizenship behaviors: Do fairness perceptions influence employee citizenship? Journal of Applied Psychology, 76(4), 845-855.

Mowday, R. T., L. W. Porter and R. M. Steers. (1982). Employee Organization Linkages: The Psychology of Commitment, Absenteeism, and Turnover. New York: Academic Press.

Neves, J., \& Bento, L. (2005). Portugal. In A. Habisch, M. Wegner, R. Schmidpeter \& J. Jonker (Eds.), Corporate Social Responsibility Across Europe (pp. 303-314): Springer Berlin Heidelberg.

Peterson, D. K. (2004a). The relationship between perceptions of corporate citizenship and organizational commitment. Business and Society, 43, 269-319.

Peterson, D. K. (2004b). The Relationship Between Perceptions of Corporate Citizenship and Organizational Commitment. Business \& Society, 43(3), 296-319.

Philip Kotler, N. L. (2005). Corporate social responsibility: Doing the most good for your company and your cause. New Jersey: John Wilson \& Sons, Inc.

Porter, M., \& Kramer, M. R. (2006). Strategy \& society: The link between competitive advantage and corporate social responsibility. Harvard Business Review, 84(12), 7892.

Qinghua Zhu, Y. H., Junjun Liu and Kee-hung Lai. (2012). How is Employee Perception of Organizational Efforts in Corporate Social Responsibility Related to Their Satisfaction and Loyalty Towards Developing Harmonious Society in Chinese Enterprises. Corporate Social Responsibility and Environmental Management.

Riordan, C. M., Gatewood, R. D., \& Bill, J. B. (1997). Corporate image: Employee reactions and implications for managing corporate social performance. Journal of Business Ethics, 16(1), 401-412. 
Rodrigo, P., \& Arenas, D. (2008). Do employees care about CSR programs? A typology of employees according to their attitudes. Journal of Business Ethics, 83, 265-283.

Rodrigo, P., \& Arenas, D. (2008). Do employees care about CSR programs? A typology of employee according to their attitudes. Journal of Business Ethics, 83, 265-283.

Rupp, D., Ganapathi, J., Aguilera, R., \& Williams, C. (2006). Employee reactions to corporate social responsibility: An organizational justice framework. Journal of Organizational Behavior, 27, 537-543.

Saari LM, J. T. (2004). Employee attitudes and job satisfaction. Human Resource Management, 43(4), 395-407.

Sean Valentine, G. F. (2008). Ethics Programs, Perceived Corporate Social Responsibility and Job Satisfaction. Journal of Business Ethics, 77, 159-172.

Sen, S., \& Bhattacharya, C. B. (2001). Does doing good always lead to doing better? Consumer reactions to corporate social responsibility. Journal of Marketing Research, 38(2), 225-243.

Sen, S., Bhattacharya, C. B., \& Korschun, D. (2006). The role of corporate social responsibility in strengthening multiple stakeholder relationships: A field experiment. Journal of the Academy of Marketing Science, 34(2), 158-166.

Sharma, S., \& Vredenburg, H. (1998). Proactive corporate environmental strategy and the development of competitively valuable organizational capabilities. . Strategic Management Journal, 19, 729-753.

Smith, P. C., Kendall, L. M., \& Hulin, C. L. . (1969). The measurement of satisfaction in work and retirement. Chicago: Rand McNally \& Co.

Spector, P. (1997). Job satisfaction: Application, assessment, causes, and consequences. CA: Sage. 
Tajfel, H. a. J. C. T. (Ed.). (1985). The Social Identity Theory of Group Behavior. Cambridge, UK: Cambridge University Press.

Teece, D. J., Pisano, G., \& Shuen, A. (1997). Dynamic capabilities and strategic management. Strategic Management Journal, 18(7), 509-533.

Trevino, L. K. a. K. A. N. (2004). Managing Business Ethics: Straight Talk about How To Do It Right

(3 ed.). New York: John Wiley and Sons, Publishers.

Turker, D. (2009). How Corporate Social Responsibility Influences Organizational Commitment. Journal of Business Ethics, 89, 189-204.

Tuzzolino, F. a. B. R. A. (1981). A Need- Hierarchy Framework for Assessing Corporate Social Responsibility. Academy of Management Review, 6(1), 21-28.

Vakola, M. a. I. N. (2005). Attitudes Towards Organizational Change: What is the Role of Employees' Stress and Commitment? Employee Relation, 25(2), 160-174.

Valentine, S., \& Fleischman, G. (2008). Professional ethical standards, corporate social responsibility, and the perceived role of ethics and responsibility. Journal of Business Ethics, 82, 657-666.

Viswesvaran, C., S. P. Deshpande and J. Joseph. (1998). Job Satisfaction as a Function of Top Management Support For Ethical Behavior Journal of Business Ethics 17, 365371.

Weiss, H. (2002). Deconstructing job satisfaction: Separating evaluations, beliefs and affective experiences. Human Resource Management Review, 12, 173-194.

Windsor, D. (2001). "Corporate Social Responsibility: A Theory of the Firm Perspective": Some Comments. The Academy of Management Review, 26(4), 502504. 
Zheng, D. (2010). The Impact of Employees' Perception of Corporate Social Responsibility on Job Attitudes and Behaviors: A Study in China. Singapore Management University, Singapore. 